Original Research Paper

\title{
Analysis of Tree-Ring Chronologies in Coniferous Forests of Southeastern Kazakhstan
}

\author{
${ }^{1}$ Ainur Utebekova, ${ }^{2}$ Bagila Maisupova, ${ }^{1}$ Bulkair Mambetov, \\ ${ }^{1}$ Daniyar Dosmanbetov, ${ }^{2}$ Nurzhan Kelgenbayev and ${ }^{3}$ Talgat Abzhanov \\ ${ }^{1}$ Kazakh National Agrarian University, Almaty, Kazakhstan \\ ${ }^{2}$ Kazakh Research Institute of Forestry and Agroforestry, Almaty, Kazakhstan \\ ${ }^{3}$ S. Seifullin Kazakh Agro Technical University, Nur-Sultan, Kazakhstan
}

\author{
Article history \\ Received: 18-09-2020 \\ Revised: 04-02-2021 \\ Accepted: 04-02-2021 \\ Corresponding Author: \\ Ainur Utebekova \\ Kazakh National Agrarian \\ University, Almaty, \\ Kazakhstan \\ Email: arunia190482@mail.ru
}

\begin{abstract}
The aim of the present research was to study the spatial and temporal patterns in the growth response of spruce to climate change at different altitudes (upper, middle and lower) of mountainous terrain in Southern Kazakhstan. The analysis of the climatic response of the generalized chronologies was carried out by calculating the correlation coefficients (Rs) between the growth indices and monthly precipitations and air temperatures for the period during which the influence of climatic factors on the annual radial increment of wood was possible. This is especially important in cases where there are no assumptions about the possible influence of climatic factors on the growth of woody plants in specific conditions. According to the research, correlation and response analysis shows that the Palmer Drought Severity Index (PDSI) from July 2015 to June 2016 was the main factor limiting the radial growth of Schrenk spruce. The PDSI showed markedly prolonged and rapid hydration from 1980 to 2005 but declined after 2005. There have been three particularly dry years over the past decade (2008, 2014 and 2015). The chronologies have been reconstructed by the PDSI for the last 189 years for the Dzungarian Alatau. A calibration model from 1950 to 2011 explains $42.6 \%$ of the actual PDSI variance. The reconstructed PDSI reflects the severe droughts of the 1910s and 1940s that were widespread in the arid zones of Central Asia. The extremely dry years in the 1910s and 1940s are especially noticeable. A ten-year analysis shows that in five periods, i.e., between the years 1830-1840, 1880-1890, 19201930, 1950-1960 and 1980-2000, the PDSI increased and decreased in the $1850-1870,1900-1910,1940$ and $1970 \mathrm{~s}$.
\end{abstract}

Keywords: Limb, Climate, Tien Shan Spruce, Radial Increment, Ecological Reconstruction

\section{Introduction}

The problem of possible climate change, in particular, the warming of the Earth's surface, is the most important among the global environmental problems that have arisen recently. It is very important to know the detailed climate history of areas located in the high latitudes of the Eurasian continent since it is here that the highest temperature variability is observed compared to areas located in the middle and low latitudes, while the ecosystems are very sensitive to these changes (IPCC, 2015).
The changes in surface air temperature in Europe are significantly influenced by the North Atlantic Oscillation. According to (Perevedentsev et al., 2005), the values of the correlation coefficients for the territory of Europe reach 0.4-0.5; at the same time, the relationship with the temperature of the near-shore layer for the water area of the North Atlantic is negative. The behavior of extreme temperatures (maximum and minimum) also indicates a warming climate in most of the Northern Hemisphere. Thus, the average minimum temperatures increased from cold to warm sub-period to $2{ }^{\circ} \mathrm{C}$ in Eurasia and the extratropical part of North 
America, except for the northwestern part of the Atlantic and its southern regions. The differences in the average maximum surface temperatures indicate a decrease in the Sahara (by $2^{\circ} \mathrm{C}$ ) and southern Asia.

Information on climate change can be obtained in many ways. Instrumental observations at weather stations provide the most reliable information about the weather of the studied area, but this information usually covers a short period of time (as a rule less than a hundred years) and the network of existing weather stations is rare, especially in mountainous areas. One of the most promising methods of studying the dynamics of individual climatic factors and the frequency of climatic extremes in the past beyond the period of instrumental observations is the dendrochronological method since the relationship between the width of the tree rings and climatic factors have been studied quite well.

For wood-ring analysis, coniferous species are most often used, since they are responsive to changes in external conditions, widespread in areas of cold and temperate climate, durable and have well-distinguishable annual growth layers, such as for example, representatives of the Pinus, Picea, Larix, Abies, Juniperus genera, etc. In this study, Schrenk spruce was chosen for climate analysis. Schrenk spruce specimens often grow up to $40 \mathrm{~m}$ in height and $70-100 \mathrm{~cm}$ in radius. In the spruce of this species, the roots are located shallow (soil depth 40-60 cm) and have strong morphological plasticity; horizontal roots are numerous. More than $90 \%$ of the forest (height above mean sea level from 1.200 to $3,000 \mathrm{~m}$ ) consists of Schrenk spruce the dominant tree species in the forests of the Dzungarian Alatau. This widespread coniferous species provides an excellent opportunity for dendrochronological studies to assess the response of tree growth to climate and longterm climate change.

\section{Literature Review}

Currently, the problem of the natural environment and climate change has become an important scientific research area. Large arrays of instrumental meteorological observations have been accumulated, whose analysis shows that indeed over the last century there have been significant climate changes both on the whole planet and in the territory of Kazakhstan. For Kazakhstan, research on climate change is important, since its natural resources and economy are significantly vulnerable to climate change due to the lack of water resources, a huge territory and the features of its geographical location in the central part of the vast Eurasian continent. Mountainous regions of southern and southeastern Kazakhstan may be vulnerable to the effects of climate change. The frequency and intensity of mudflows and avalanches are expected to increase with possible climate change. The expected rise in the water level in the Caspian Sea, combined with storms, will lead to an increase in seawater levels. An increase in the level of the Caspian Sea will lead to an increase in the level of groundwater in the coastal zone. The expected economic and social damage caused by climate change in these areas is significant (Mátyás, 2010).

However, there is a problem of comparing the condition of the environment and climate of the last hundred years with those of the past centuries and millennia. Thus, it is problematic to give a correct assessment of present-day changes in the historical perspective or to make reliable forecasts of the natural environment and the climate system development, based on a short series of instrumental observations.

In dendroclimatology, the need to separate the influence of external climatic factors on the increment of trees and the natural internal variability present in dendrochronological measurements has led to the creation of specific methods called standardization (Briffa and Jones, 1990). Leaving aside applications of the dendrochronological method such as the study of individual characteristics of trees and ecological features of habitat, further, the focus will be made on the dendroclimatic aspect. The problem of dendrochronological data standardization is one of the key and urgent problems in modern dendroclimatology. The possibility of using dendrochronological data to restore long-period climate variability is discussed especially extensively (Esper et al., 2002; Fritts, 1976).

At the very core of the standardization of tree ring width series is the fact that as the tree matures and grows in size, the tree ring width tends to decrease along the transverse radius, mainly due to the geometric restriction on adding new layers of wood over the increasing surface (Solomina et al., 2014).

The widespread use of annual growth layers to solve a variety of scientific and practical problems is due to the fact that wood plants are one of the longest-living organisms on land. Maximum age, to which trees and shrubs live, is noted in a large number of publications. At the same time, unreliable data are often used, based mainly on visual estimates of the size of trees as well as legends. As a rule, large trees are not the oldest ones. In addition, the exact age of most old trees cannot be determined due to the fact that many of them have a hollow in the center of the trunk. The currently available reliable data testify that the longest-lived species is the Bristlecone Pine (Pinus aristata Engelm). This kind of pines grows on the upper border of the forest in the mountains of the Southwestern United States. The oldest specimen of this species found to date, which was unfortunately felled, was 4,900 years old. Quite an old age $(3,200$ years) can be reached by Big Tree (Sequoiadendron giganteum Lindl.). Many species of trees live to 1,000-2,000 years, including the Turkestan juniper (Juniperus turkestanica Kom.) native to the highlands of Central Asia. In the territory of Russia, 
many coniferous and deciduous species reach the age of 400-600 years, while the most long-lived species are Kayandera larch (Larix cajanderi Mayr.) living over 1,000 years and Siberian juniper (Juniperus sibirica Burgsd.), living up to 900 years (Melekhov, 1979).

Dendrochronological methods are widely used to solve scientific and practical problems in various fields of knowledge (ecology, geography, climatology, hydrology, oceanology, heliophysics, archaeology, history, ethnography, etc.), including forest science and forestry. The most important and promising area of forest science and forestry research when using dendrochronological methods is studying the spatialtemporal dynamics of forest ecosystems under the influence of natural and anthropogenic factors. When dating and studying the phenomena and processes occurring in forest stands, the information contained in annual growth layers of wood is used basically. The range of issues addressed in this area is very extensive. It includes also the analysis of changes in the composition and structure of forest stands, including overtime intervals exceeding the maximum age of living trees. For a particular forest type and location, it is possible to obtain much more accurate and detailed information, since tree-ring analysis allows dating the time of emergence of new generations of trees and the timing of the deadwood and windfall death over a long period of time (tens and hundreds of years) (Tishin, 2011).

\section{Study of the Annual Production of Trees and Forest Stands}

Based on the data on the variability of the radial increment, calculations of other indicators of wood product (cross-sectional area, volume increment) can be made. The use of such data makes it much easier to identify the role of individual factors affecting the productivity of trees and forest stands. The analysis of variability of various indicators of annual growth of wood allows estimating the change of ranks of trees in a forest stand during age and restoration changes, studying intraspecific and interspecific interrelations in a forest stand, as well as the dynamics of botanical and geographical zones and boundaries, especially, such as the upper, lower, northern and southern boundaries of the woody vegetation distribution and the boundaries between forest and treeless cenosis.

This method also allows dating catastrophic phenomena in the forest (fires, windfalls, logging, outbreaks of insect reproduction, etc.) in order to study their repeatability and post-catastrophic changes of forest vegetation, as well as reconstructing climatic and hydrological conditions over long time intervals (hundreds and thousands of years) with high resolution (season and year-based), which have the most significant impact on the growth, composition, structure and dynamics of forest ecosystems. Besides, the method allows assessing the effectiveness of various forestry activities (drainage, fertilization, intermediate felling, etc.), as well as the impact of anthropogenic factors (industrial pollution, road construction, industrial and civil facilities, mining, recreation, grazing, mowing, etc.) on the forest ecosystems condition.

\section{Materials and Methods}

The research work was carried out in the territories of Dzungarian Alatau State National Park (Sarkand Branch of Topolevskoe Forestry, Nikonova Griva stow, sq. 41 (2,071 m MASL, N 45 18.231 , E 80 22.415 and 1,627 m MASL, N 45020.784, E 80 19.262) and Sarkand Branch of Aksu Forestry, Kiikbay stow, sq. 54 (1,799 m MASL, $\mathrm{N} 45^{0} 12.793$, E $079^{0} 58.351$ and $1,780 \mathrm{~m}$ MASL, N $45^{0} 12.470$, E $79^{0} 58.022$ ) to set up dendrochronological polygons concerning the altitude gradient of the coniferous forest belt of the Dzungarian Alatau.

To take dendro samples (cores) from living trees, we used a Swedish increment borer Haglöf (Fig. 1), with which radial cores of wood with a diameter of 4-5 mm and a length of $10-50 \mathrm{~cm}$ were drilled. Cores were taken at a height of 1.0-1.3 m from the ground surface (Fig. 2).

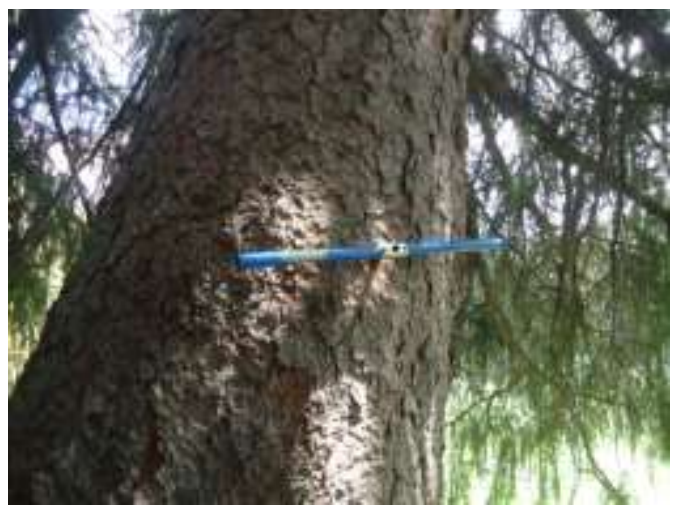

Fig. 1: Cores were sampled using a Haglöf borer

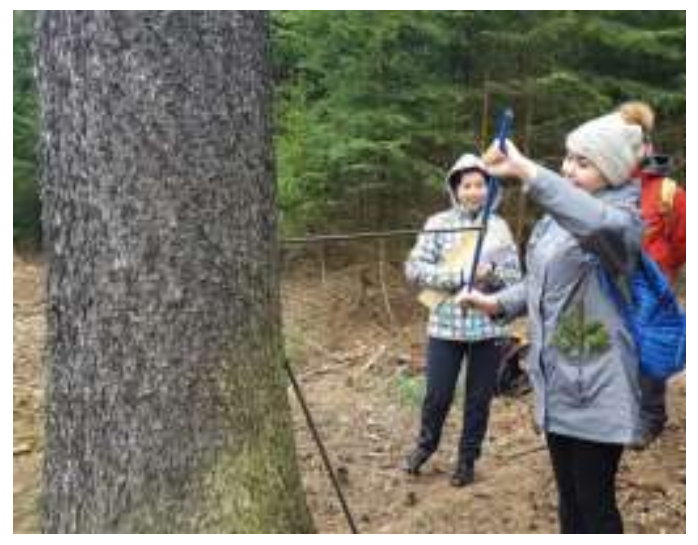

Fig. 2: Core sampling 
To build one generalized chronology, wood samples were taken from 15-30 trees of the same species; from each tree, cores were taken along two radii. Drilled cores were placed in specially prepared paper or polyethylene containers, whose inner diameter was 2-3 mm larger than the sample diameter. Samples placed in containers were convenient to transport, dry and store before conducting dating and measurement of the rings (Fig. 3).

On a wood sample or container, the type of tree, date of sampling, name of the collector, etc. were indicated. Each trial plot describes the coordinates of the area, growing conditions, soil, the vegetation of model trees and taken wood samples (Shiyatov et al., 2000; Maysupova et al., 2016).

Following standard dendrochronological methods, the cores of the tree rings were dried naturally and mounted on a corrugated wooden plank (Fig. 4).

Each dendro sample was sanded with low and high cell number sandpaper until the growth ring cells were visible under a microscope (Fig. 5). Then ten-year, halfcentury and century annual rings in each nucleus were marked with different signs using needles under a microscope. The width of each ring was measured using a binocular microscope with a resolution of $0.001 \mathrm{~mm}$.

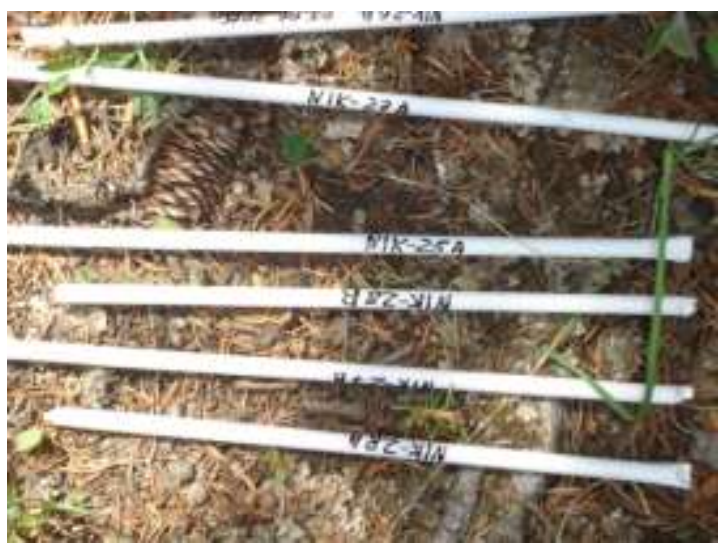

Fig. 3: Specially prepared paper containers

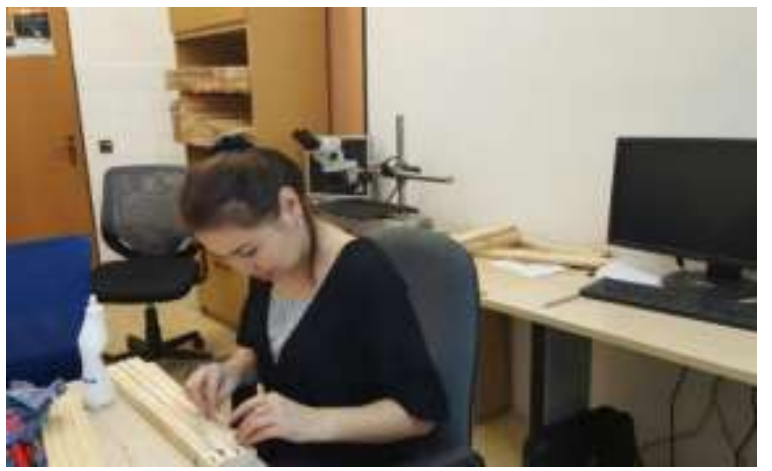

Fig. 4: Preparing cores for measurement
To increase the contrast of the boundaries between cells and growth rings, the surface was wetted with water. For dating and measuring the width of the growth rings, we used the dry method, that is, rubbed powdered chalk on the cleaned surface with a piece of cotton wool. The dry method is convenient in that there is no need to constantly keep the sample in a wet state and distortions associated with wood swelling are eliminated (Fig. 6).

The samples were pre-processed using standard dendrochronological procedures at the China Meteorological Administration's Key Laboratory of Tree-ring Physical and Chemical Research. The width of the rings was measured with an accuracy of 0.001 mm using the Lintab system (Germany) after visual cross-dating (Zhang et al., 2019). Rows of ring widths were visually compared with graphs and the dating was checked using the COFECHA program (Grissino-Mayer, 2001). Growth ring width chronologies were developed using the ARSTAN program (Cook and Krusic, 2005).

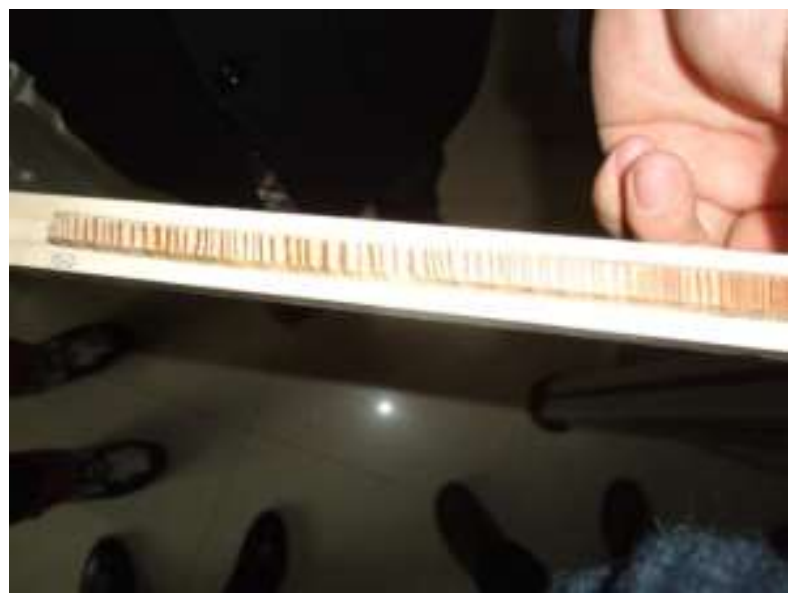

Fig. 5: Well-cleaned Schrenk spruce sample

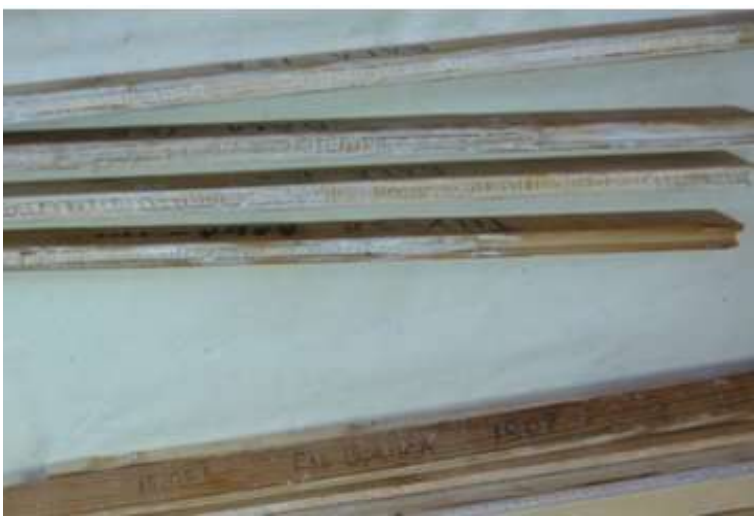

Fig. 6: Spruce dendro samples after primary processing 


\section{Results}

The species composition, ecology and the number of forest insects and pests were determined, as well as the age in different height gradients of the coniferous forest belt of the Dzungarian Alatau. The analysis of crossdating of wood-ring series by the width of tree rings is given. A number of issues about the spatial and temporal patterns in changing the ecology of coniferous forests in the mountainous regions of Southeastern Kazakhstan were studied. The variability of radial increment depending on cores from live trees of Schrenk spruce was revealed. The analysis of the restoration of a weather sequence of changes in climate and ecological situation of recent years within the above-mentioned gorges of the Dzungarian Alatau is given.

The calculation of tree-ring chronologies of Schrenk spruce and tree chronology were carried out, as well as correlation and response analysis, showing that dryness index from the previous July to the current June was the main factor limiting radial growth. For the Dzungarian Alatau, the chronology was used to reconstruct the dryness index for the last 189 years.

The calibration model for the periods from 1950 to 2011 explains the $42.6 \%$ (or $41.7 \%$ after adjusting for the loss of degrees of freedom) of actual dispersion of the dryness index. The reconstructed dryness index can represent drought conditions for much of the site under study because it captures severe drought events that occurred in the 1910 and 1940 s which were widespread in Central Asian countries. The extreme droughts of 1917 and 1945 are particularly pronounced. The decadal analysis shows the five periods in which the dryness index trend increased. These are the following periods: $1830-1840,1880-1890,1920-1930,1950-1960$ and 1980-2000. The dryness index was declining in the periods of 1850-1870, 1900-1910 and 1940-1970. The dryness index in arid regions has shown long wet periods from 1980 to 2005, while it decreased after 2005. Over the past ten years, in fact, there have actually been three particularly dry years of 2008, 2014 and 2015.

The statistical characteristics of the chronology are presented in Table 1.

Table 1: Statistical characteristics of the Tree-Ring Chronologies (TRC)

\begin{tabular}{ll}
\hline Statistics & TRC \\
\hline Average Sensitivity Coefficient (ASC) & 0.213 \\
Standard Deviation (SD) & 0.251 \\
Autocorrelation of the first order & 0.458 \\
The average correlation between all series & 0.698 \\
The average correlation between the trees & 0.668 \\
Average correlation in the tree & 0.820 \\
Signal-to-Noise Ratio (SNR) & 11.568 \\
The difference in the first eigenvector, \% & 81.5 \\
Expressed Population Signal (EPS) & 0.920 \\
In the first year SSS > 0.95 (the number of trees) & $1,828(5)$ \\
\hline
\end{tabular}

The average correlation among trees indicates the strength of the overall signal among the set. Mean correlation, mean correlation in a tree and mean correlation among trees in tree-ring chronology are high, correlation coefficients are 0.698 (P<0.01), 0.820 $(\mathrm{p}<0.01)$ and $0.668(\mathrm{p}<0.01)$, respectively.

In general, the ASC, SD, EPS and SNR are thought to indicate greater climatic influence on tree growth. The standard tree-ring chronology of has high ASC (0.213), SD (0.251), EPS (0.920) and SNR (11.568). The results indicate the presence of strong climate information in the standard tree-ring chronology.

\section{Discussion}

The research results have shown that moisture plays an important role in the growth of Schrenk spruce and drought (from late May to late June) in the Northern Tian Shan is a limiting factor for its radial increment.

Studies by many scientists have shown that the dominant factor affecting the radial increment of Schrenk spruce is the drought conditions of the previous and current growing seasons (Zhang et al., 2017).

In Russia by now, several continuous tree-ring chronologies lasting from 5-7 to 10-12 thousand years have been constructed. The first longtime chronology (8,700 years) was built based on the Bristlecone Pine growing on the upper border of the forest in the mountains of the Southwestern United States. It is based on the use of very old live pines, reaching the age of 3,500-4,900 years, as well as deadwood, which in conditions of dry air and soil, as well as the absence of fires persisted for many thousands of years. In total, about a dozen chronologies covering more than three thousand years were built in the southwest of the United States. These chronologies were built using also Pinus balfouriana and Big Tree in addition to Bristlecone Pine. A few longtime chronologies are available for the southern hemisphere (Tasmania Island and Western part of South America). A large number of well-preserved trunks of ancient oak wood are found in peat and alluvial deposits of Western Europe. Based on the use of this wood, long-term chronologies were built. Among them, the longest is the one for southern regions of Germany (over 9,900 years-long), slightly shorter series are available for Northern Germany (over 9,200 years-long) and Northern Ireland (over 7,300 years-long). Superlong chronologies for subarctic regions are of particular interest because they contain a strong climatological aspect. Such absolute chronologies are constructed for the north of Scandinavia based on the common pine (2,165 years-long), while for the subarctic zone of Russia, four chronologies were built based on larch lasting more than 1,000 years: For the Polar Urals $(1,250$ years-long), the Yamal Peninsula ( 7,000 years- 
long), the Taimyr Peninsula (2,600 years-long) and the lower reaches of the Indigirka River (2,500 years-long) (Vakhnina, 2011).

Long-term tree-ring chronologies are widely used to solve various scientific and practical problems, primarily for the reconstruction of changes in environmental conditions and dynamics of forest ecosystems, as well as for absolute dating of historical and archaeological sites and the latest geological deposits.

Moisture in the current growing season directly increases soil moisture, thereby compensating for the loss of soil moisture due to total evaporation.

Indeed, the climatic conditions of the preceding autumn, winter and spring may play an important role. Moisture during the previous winter improves the moisture accumulation in the soil, which is crucial for growth in the coming year.

Extreme droughts in 1917 and 1945 were also observed in Mongolia (Pederson et al., 2001). The results of a decade-long analysis of changes for the Dzungarian Alatau over the past 189 years are consistent with other studies in the ACA (Arid Central Asia). Foreign scientists have noted that global warming is expected to increase the frequency and intensity of droughts in the 21st century (Bitvinskas et al., 1990; Jiang et al., 2017). To test the reliability and versatility of this trend, the authors have compared the reconstructed series with meteorological data from nearby Almaty stations using monthly meteorological data on precipitation.

\section{Conclusion}

Based upon the results obtained, the Dzungarian Alatau has shown rapid and prolonged periods of moisture starting from 1980 to 2005. However, after 2005 and three consecutive dry years (2008, 2014 and 2015), this trend has been registered only over the past 10 years. Meteorological data from a nearby weather station confirm this drought trend, but yet it is not clear which trend is represented by climate transition, thus continuous monitoring and further research are necessary (Zhang et al., 2017).

\section{Acknowledgement}

This work was supported by the Ministry of Education and Science of the Republic of Kazakhstan under the budget program No. 055 "Scientific and/or scientific and technological practices", subprogram No. 101 "Grant funding of scientific research" on the topic: "Monitoring of changes in the ecology of coniferous forests in time and space in the south-east of Kazakhstan by dendrochronological analysis methods " (Agreement No. 129 of February 12, 2015, Astana). The authors express their gratitude to anonymous experts for helpful comments to improve the manuscript. The authors express their special gratitude to the employees of the Almaty branch of the Kazakh Scientific Research Institute of Forestry and Agroforestry LLP and dendrochronology laboratory of the Institute of Desert Meteorology of the China Meteorological Administration of Urumqi.

\section{Author's Contributions}

All authors equally contributed in this work.

\section{Ethics}

This article is original and contains unpublished material. The corresponding author confirms that all of the other authors have read and approved the manuscript and no ethical issues involved.

\section{References}

Briffa, K. R., \& Jones, P. D. (1990). Measuring the statistical quality of a chronology. Methods of dendrochronology: applicationsin the environmental sciences (Ed. by ER Cook and LA Kairiukstis).Boston, Mass., USA: Kluwer Academic Publishers, 137-152.

Bitvinskas, T., Briffa, K., Cook, E., Downing, D. J., Dubinskaite, J., Eckstein, D., ... \& Worbes, M. (1990). Methods of dendrochronology: applications in the environmental sciences.

Cook, E. R., \& Krusic, P. J. (2005). Program ARSTAN: a tree-ring standardization program based on detrending and autoregressive time series modeling, with interactive graphics. Lamont-Doherty Earth Observatory, Columbia University, Palisades, NY.

Esper, J., Cook, E. R., \& Schweingruber, F. H. (2002). Low-frequency signals in long tree-ring chronologies for reconstructing past temperature variability. science, 295(5563), 2250-2253.

Fritts, H. C. (1976). Tree rings and climate Academic Press. New York.

Grissino-Mayer, H. D. (2001). Evaluating crossdating accuracy: a manual and tutorial for the computer program COFECHA.

IPCC. (2015). Climate Change. 2014. A Report of the Intergovernmental Panel on Climate Change. https://epic.awi.de/id/eprint/37530/1/IPCC_AR5_S YR_Final.pdf

Jiang, P., Liu, H., Wu, X., \& Wang, H. (2017). Tree-ring-based SPEI reconstruction in central Tianshan Mountains of China since AD 1820 and links to westerly circulation. International Journal of Climatology, 37(6), 2863-2872.

Mátyás, C. (2010). Forests and climate change in Eastern Europe and Central Asia (Vol. 8). FAO. 
Maysupova, B. D., Mambetov, B. T., \& Kelgenbaev, N. S. (2016). Vybor ob"ektov dendrohronologicheskih issledovanij i otbor obrazcov drevesiny [Selection of dendrochronological research objects and wood sampling]. Science News of Kazakhstan, 3(129): 159-177. http://www.vestnik.nauka.kz/selskoe-ilesnoe-xozyajstvo/vybor-obektov-

dendroxronologicheskix-issledovanij-i-otborobrazcov-drevesiny.php

Melekhov, I. S. (1979). Znachenie struktury godichnyh sloev $i$ eyo dinamiki $v$ lesovodstve i dendroklimatologii [The importance of annual growth layer structure and its dynamics in forestry and dendroclimatology]. Bulletin of the Higher Education Institutions. Forest Journal, 4: 6-14. http://lesnoizhurnal.ru/article_index_years.php?artic le $=66278$

Pederson, N., Jacoby, G. C., D’Arrigo, R. D., Cook, E. R., Buckley, B. M., Dugarjav, C., \& Mijiddorj, R. (2001). Hydrometeorological reconstructions for northeastern Mongolia derived from tree rings: 1651-1995. Journal of Climate, 14(5), 872-881.

Perevedentsev, Y. P., Vereshchagin, M. A., Naumov, E. P., Shantalinsky, K. M., \& Nikolaev, A. A. (2005). Sovremennyye izmeneniya klimata Severnogo polushariya Zemli [Modern Climate Changes in the Northern Hemisphere of the Earth]. Uchenyye zapiski Kazanskogo gosudarstvennogo universiteta. Yestestvennyye nauki, 147(1): 90-106. https://repository.kpfu.ru/eng/?p_id=10336\&p_lang=2

Shiyatov, S.G., E.A. Vaganov, A.V. Kirdyanov, V.B. Kruglov, V.S. Mazepa, M.M. Naursbayev and R.M. Khantemirov. 2000. Metody dendrohronologii. Chast' I: Osnovy dendrohronologii. [Methods of dendrochronology. Part I: Fundamentals of dendrochronology]. Collection and reception of treering information, Educational and methodical manual. Krasnoyarsk State University, Krasnoyarsk. ISBN 5-7638-0295-0 https://www.booksite.ru/fulltext/rusles/shiy/text.pdf
Solomina, O., Maximova, O., \& Cook, E. (2014). Picea schrenkiana ring width and density at the upper and lower tree limits in the Tien Shan Mts (Kyrgyz Republic) as a source of paleoclimatic information. Geography, Environment, Sustainability, 7(1), 66-79.

Tishin, D. V. (2011). Dendroekologiya (metodika drevesno-koltsevogo analiza) [Dendroecology (method of tree-ring analysis)]. Kazanskiy universitet, Kazan. http://libweb.kpfu.ru/ebooks/02IEG/02_82_000873.pdf

Vakhnina, I. L. (2011). Analiz dinamiki shiriny godichnyh kolec sosny obyknovennoj v usloviyah Vostochnogo Zabajkal'ya [The analysis of common pine tree rings width dynamics in the context of Eastern Transbaikalia]. Bulletin of Irkutsk State University, 4(3): 13-17. http://inrec.sbras.ru/files/public/1423641291.pdf

Zhang, R., Zhang, T., Kelgenbayev, N., He, Q., Maisupova, B., Mambetov, B. T., ... \& Yuan, Y. (2017). A 189-year tree-ring record of drought for the Dzungarian Alatau, arid Central Asia. Journal of Asian Earth Sciences, 148, 305-314.

Zhang, T., Zhang, R., Jiang, S., Bagila, M., Ainur, U., \& $\mathrm{Yu}$, S. (2019). On the 'Divergence Problem'in the Alatau Mountains, Central Asia: A Study of the Responses of Schrenk spruce Tree-Ring Width to Climate under the Recent Warming and Wetting Trend. Atmosphere, 10(8), 473. 